\title{
Hirschsprung Disease: A Review
}

\author{
Reda A Zbaida* \\ Division of pediatric surgery, Stellenbosch university, South Africa
}

Submission: September 17,2019; Published: September 27, 2019

*Corresponding author: Reda A Zbaida, Division of pediatric surgery, Stellenbosch university, Cape town, South Africa

\section{Abstract}

Hirschsprung disease is the most common cause of low functional bowel obstruction in the pediatric age group, which caused by a complex genetic mutations which interfere with normal development of the enteric nervous system, about $2 / 3$ of the cases presented as isolated disease, the other cases could present with congenital anomalies or within syndromic context, the surgical intervention consider curable for most of the cases provided it the surgical technique applied meticulously.

Keywords: Hirschsprung's Disease; Pediatric; Ganglionic; Anastomosis; Achalasia

\section{Introduction}

Hirschsprung's disease is a complex genetic disorder of the enteric nervous system which leads to functional intestinal obstruction, HD considered the most common cause of distal intestinal obstruction in the pediatric age group [1]. The disease named after Danish pathologist who credited with first description of clinical features of disease, [2] and he concluded erroneously that the pathology was in the proximal dilated bowel, after almost half-century Dr Swenson et al in his landmark paper (Hirschsprung's disease: A new concept of the etiology) recognized the distal spastic rectum and colon are the site of obstruction [3]. since then different surgical techniques have been described all of them based on excision of the a ganglionic segment and anastomosis of the ganglionated bowel to the rectum, surgery is considered curative for most HD cases, It worth mentioning that the knowledge about congenital megacolon has been documented in prehistoric India nearly 4000 years before Harlod Hirschsprung, amazingly they referred the cause of the disease to defect in nerves and prescribed sigmoid colostomy as treatment for the disease [4]. The worldwide incidence of HD is 1:5000, [5] with Male: female ratio of 4:1, [6] the length of the diseased bowel affects M:F ratio till becoming almost the same 1.5:1 in total colonic aganglionosis [7]. HD grouped according to the length of the aganglionic segment which always start distally at the internal sphincter and extend proximally to variable distances, [5] which classified into short segment (rectosigmoid) which include $80 \%$ of HD patients, Total colonic aganglionosis which extends proximally at least the ileocecal valve but not $>50 \mathrm{~cm}$ of small bowel, the long segment category is located between the previous 2 categories, and finally Zuezler syndrome (very-long-segment) which extends for $>50 \mathrm{~cm}$ of small bowel, $[7,8]$ the ultra-short segment now replaced by the internal anal sphincter achalasia, which is more accurate for pathologic entity [9].

\section{Etiology}

The normal peristalsis movement of intestine controlled by the enteric nervous system, [10] ENS controls the physiology of the gastrointestinal tract largely independently via a network of nerves within intestine's wall and has neurons and glial cells more than the spinal cord which located in the myenteric and submucosal ganglia $[5,11]$. The absence of ganglion cells led to persistent spastic in the affected part which manifests clinically as functional intestinal obstruction with dilated proximal bowel (HD) [12]. This happens due developmental error of ENS during fetal life, which interferes with the migration process of crest cells (ectoderm) from the sides of the neural tube to the bowel wall mainly via vagal trunk the process takes place between 5-12 weeks of fetal life aboral manner [1,13]. This normal process controlled by complex interacting genetic singling pathways, [14] mutations of 10 genes have involved in HD development [15]. RET gene (REarranged during Transection) mutation cause most familial cases of HD, [12] the relative risk of recurrence in the affected families as high as 200 [15].

\section{Associated anomalies}

$70 \%$ of HD cases are isolated, $12 \%$ associated with chromosomal abnormalities, and $18 \%$ associated with congenital anomalies [15]. The associated anomalies include intestinal 
malrotations, genitourinary abnormalities, congenital heart disease, and cleft palate, [13] regarding the syndromes by far the most common one is Trisomy 21 (>90\%), [15] the rest of the syndromes fall under category what is known as "Neurocristopathy Syndromes" [13]. Bolande the first how suggested to use term "Neurocristopathies" referring to wide variety of diseases the neural crest cells get involved in, $[16,17]$ that's because the neural crest cell in addition to their role in ENS formation, they spread throughoutbody and participate in many tissue development which include Adrenal medulla, facial cartilages, Odontoblasts, pigment cells, and Schwann cells, [12] in this context many syndromes make sense like Shah Waardenburg syndrome, Haddad syndrome, and MEN 2 syndromes due to serious consequences of elements of some these syndromes some authors suggest that all HD patients need to be examined early in the life by Dysmorphologist for early diagnosis of these syndromes [15].

\section{Clinical presentation}

80\%-90\% of HD patients diagnosed in the neonatal period, [5] typically patients present with delayed passage of meconium, bile stained vomiting, and abdominal distension. The diagnosis of HD could be delayed at later stages especially short segment, mainly in developing countries, these patients always present with chronic constipation and often malnourished, sometimes constipation severe enough to cause urogenital complications Vesico-ureteric reflux, Hydronephrosis [1,13]. HD patients could present with fever, abdominal distension, and diarrhea which are clinical manifestation of bowel's inflammations known as Hirschsprung associated enterocolitis (HAEC), which is the main cause of mortality and morbidity in HD patients [18]. The etiology of HAEC is not completely understood, [19] but theories have been proposed which include: the stasis due to mechanical obstruction, dysbiosis of intestinal microbiome, also impaired mucin and immunoglobulin production, $[13,18]$ also it has been suggested the loss of neurotropic and hematopoietic role of RET gene (mutation), and impaired function CD18 cells and T regulatory cells due to mutation in ITGB2 gene also responsible for improper immune response [20]. The risk factors for HAEC prior to surgery are Trisomy 21, long aganglionic segment, family history, and previous episodes, $[18,19]$ the risk factors post-surgery include any cause of obstruction like twisted pull-through, tight muscular cuff (Soave procedure), or Transitional zone pull-through, and it could happen post-operatively due to motility disorder.

\section{Abdominal $\mathrm{X}$ rays}

The abdominal X-ray of uncomplicated HD usually reveals distal obstruction (no air in the rectum), proximal dilated bowel with air-fluid level, and presence sawtooth appearance in bowel's wall, pneumatosis, or/and free air with pervious signs usually indicate presence of HAEC, [19] the X-ray is adjunct in making diagnosis of HACE, the diagnosis of HAEC should be made clinically. The sensitivity of X-rays to make a diagnosis of HD in uncomplicated cases around 52\% [1].
Contrast enema: It usually the next step after abdominal $\mathrm{X}$ rays, the sensitivity of this test about $65 \%$, [2] which reveals typically contracted rectum (short segment), transitional zone, then followed by dilated sigmoid (inverted recto-sigmoid ratio) [21]. It important to use water-soluble contrast enema, because it has a therapeutic effect for other differential diagnoses of HD like meconium plug, and meconium ileus [13].

Rectal biopsy: The histology is a gold standard technique for HD diagnosis, [22] which is obtained by rectal suction technique which done in the ward or clinic because the biopsies above the sensitive zone of anal canal (above the dentate line), this technique suitable for patients under age of 3 years old, [23] older patients need full-thickness biopsy which has to done under general anesthesia in the operating room. Typical histological picture of HD includes the absence of ganglion cells in myenteric and submucosal ganglia with a thickness of nerve bundles [22].

Anorectal manometry: Most HD patients diagnosed in the neonatal period, this technique not easy to perform in this particular age group, [13] which makes this technique limited in use in HD diagnosis.

\section{Preoperative management}

The definitive treatment of most HD patients is the surgical procedure, it is important to decompress the abdominal distension to prevent HAEC by gentle rectal washout during the waiting time for surgery, in cases of HAEC in addition to the rectal washout, patients will need board spectrum antibiotics, whether patients can eat or not depending how sick they are, [19] obviously intravenous fluids is required if a patient kept NPO, in severe cases of HAEC the diversion colostomy may be required, it is important not to miss HAEC cases and misdiagnose them as cases of gastroenteritis to avoid serious consequences.

Surgical techniques: Multiple surgical techniques have been in use since Swenson described the first definitive surgery for HD, [2] but all based on the same principles which include removing an aganglionic segment, anastomose the proximal ganglionated bowel to the rectum with preservation of the continence which can be achieved by protecting the dentate line and sphincter mechanism. The trend now toward Trans-anal pull-through which described by De la Torre and Ortega Salgade in 1998, [24] some comparative studies show favorite outcome of the primary pullthrough over the classical approaches, $[25,26]$ but we can see the other side of the coin in Nordic multicenter long term assessment after primary pull-through showed the fecal incontinence was most common problem, [27] which is thought due to over-stretch effect on the sphincter mechanism, which is demonstrated by manometry and endorectal endoscopy [28]. To avoid this particular complication De la Torre [24] has recommended to the surgeons to use fine sutures at proximal edge of the mucosa to provide traction, so most dissection can be done without applying retraction on the sphincter mechanism, [29] Andrea Bischoff et al in review of fecal incontinence after surgical repair of HD 
concluded that this complication can be avoided by applying a meticulous surgical technique [30].

\section{Post-operative complications}

We can divide them broadly under 2 categories

a) obstructive symptoms: which may due to mechanical obstruction (Transitional zone pull-through, strictures, tight cuff, twisted pull-through), motility disorder, or functional megacolon, [31] after the workup to find out the underlying cause, the management directed to treat it.

b) Soiling (Incontinence) symptoms: it is important to emphasize on that all HD patients borne with intact continence mechanism, [32] So fecal incontinence due damage anal canal should not happen and it is totally avoidable, but there are other reasons for soiling like overflow incontinence (constipation) which can treat it with laxative, or due to hypermotility colon the constipating diet and Loperamide can be helpful in this condition [32].

\section{References}

1. Moore SW (2016) Hirschsprung disease: current perspectives. 9: 3950.

2. Fallis A (2013) Ashcraft's pediatric surgery. Journ of Chem Infor and Model 53: 1689-1699.

3. Swenson O, Rheinlander HF, Diamond I (1949) Hirschsprung's disease; a new concept of the etiology; operative results in 34 patients. $\mathrm{N}$ Engl J Med 241(15): 551-556.

4. Raveenthiran V (2011) Knowledge of ancient Hindu surgeons on Hirschsprung disease: evidence from Sushruta Samhita of circa 1200600BC. J Pediatr Surg 46(11): 2204-2208.

5. Puri P (2011) Newborn Surgery. $3^{\text {rd }}$ Edn 554-565.

6. Parahita IG, Makhmudi A, Gunadi (2018) Comparison of Hirschsprungassociated enterocolitis following Soave and Duhamel procedures. J Pediatr Surg 53(7): 1351-1354.

7. Moore SW (2012) Total colonic aganglionosis in Hirschsprung disease. Semin Pediatr Surg 21(4): 302-309.

8. Granström AL, Husberg B, Nordenskjöld A, Svensson PJ, Wester T (2013) Laparoscopic-assisted pull-through for Hirschsprung's disease, a prospective repeated evaluation of functional outcome. J Pediatr Surg 48(12): 2536-2539.

9. Puri P, Gosemann JH (2012) Variants of Hirschsprung disease. Semin Pediatr Surg 21(4): 310-318.

10. Barret K, Brooks H, Boitano S, Barman S (2011) Ganong's review of medical physiology. $2011^{\text {th }}$ Edn

11. Weber D, Harris J, Bruns T, Mushahwar V (2017) Anatomy and physiology of the central nervous system. Neuroprosthetics Theory Pract Second Edn 40-103.

12. Embryology G, Embryology S part one General Embryology. Langman'S Med Embryol 300-304.

13. Avansino JR, Levitt MA (2016) Hirschsprung disease $7^{\text {th }}$ Edn Fundamentals of Pediatric Surgery, Second Edition. Elsevier Inc.; 2016. 513-524.

14. Tam PKH, Garcia-barcelo M (2004) Molecular genetics of Hirschsprung's disease. 236-248.
15. Amiel J, Sproat Emison E, Garcia Barcelo M, Lantieri F, Burzynski G et al. (2008) Hirschsprung disease, associated syndromes and genetics: A review. J Med Genet 45(1): 1-14.

16. Bronner Fraser M (1993) Segregation of cell lineage in the neural crest. Curr Opin Genet Dev 3(4): 641-647.

17. Martucciello G, Lerone M, Bricco L, Tonini GP, Lombardi L, et al. (2012) Multiple endocrine neoplasias type 2B and RET proto-oncogene. Ital J Pediatr 38: 9 .

18. Gosain A, Frykman PK, Cowles RA, Horton J, Levitt M, et al. (2017) Guidelines for the diagnosis and management of Hirschsprungassociated enterocolitis. Pediatr Surg Int 33(5): 517-521.

19. Frykman PK, Short SS (2017) Hirschsprung-associated enterocolitis : prevention and therapy Early diagnosis. YSPSU 21(4): 328-335.

20. Moore SW (2016) Genetic impact on the treatment \& management of Hirschsprung disease. J Pediatr Surg 52(2): 218-222.

21. Andronikou S, Alexander A, Kilborn T, Millar AJW. ABC of Pediatric Surgical.

22. Muise ED, Cowles RA (2016) Rectal biopsy for Hirschsprung's disease: a review of techniques, pathology, and complications. World J Pediatr 12(2): 135-341.

23. Spitz L, Coran AG (2013) Operative pediatric surgery. $7^{\text {th Edn The British Journal }}$ of Psychiatry 111: 1009-1010.

24. De La Torre Mondragón L, Ortega-Salgado JA (2017) Transanal endorectal pull-through for Hirschsprung's disease. J Pediatr Surg 33(8): 1283-1286.

25. Kim AC, Langer JC, Pastor AC, Zhang L, Sloots CEJ, et al. (2010) Endorectal pull-through for Hirschsprung's disease-A multicenter, long-term comparison of results: transanal vs transabdominal approach. J Pediatr Surg 45(6): 1213-1220.

26. Chen Y, Nah SA, Laksmi NK, Ong CCP, Chua JHY, et al. (2013) Transanal endorectal pull-through versus transabdominal approach for Hirschsprung's disease: A systematic review and meta-analysis. J Pediatr Surg 48(3): 642-651.

27. Bjørnland K, Pakarinen MP, Stenstrøm P, Stensrud KJ, Neuvonen M, et al. (2017) A Nordic multicenter survey of long-term bowel function after transanal endorectal pull-through in 200 patients with rectosigmoid Hirschsprung disease. J Pediatr Surg 52(9): 1458-1464.

28. Stensrud KJ, Emblem R, Bjørnland K (2015) Anal endosonography and bowel function in patients undergoing different types of endorectal pull-through procedures for Hirschsprung disease. J Pediatr Surg 50(8): 1341-1346.

29. De La Torre L, Langer JC (2010) Transanal endorectal pull-through for Hirschsprung disease: technique, controversies, pearls, pitfalls, and an organized approach to the management of postoperative obstructive symptoms. Semin Pediatr Surg 19(2): 96-106.

30. Bischoff A, Frischer J, Leslie J, Dickie B, Levitt MA, et al. (2017) Damaged anal canal as a cause of fecal incontinence after surgical repair for Hirschsprung disease-a preventable and under-reported complication. J Pediatr Surg 52(4): 549-553.

31. Langer JC, Rollins MD, Levitt M, Gosain A, de la Torre L, et al. (2017) Guidelines for the management of postoperative obstructive symptoms in children with Hirschsprung disease. Pediatr Surg Int 33(5): 523-526.

32. Levitt MA, Martin CA, Olesevich M, Bauer CL, Jackson LE, et al. Hirschsprung disease and fecal incontinence: diagnostic and management strategies. J Pediatr Surg 44(1):2 71-277. 
This work is licensed under Creative

Commons Attribution 4.0 Licens

DOI: 10.19080/AJPN.2019.08.555786
Your next submission with Juniper Publishers

will reach you the below assets

- Quality Editorial service

- Swift Peer Review

- Reprints availability

- E-prints Service

- Manuscript Podcast for convenient understanding

- Global attainment for your research

- Manuscript accessibility in different formats

( Pdf, E-pub, Full Text, Audio)

- Unceasing customer service

Track the below URL for one-step submission

https://juniperpublishers.com/online-submission.php 